\title{
Amino acid and biogenic amine composition of Busha cattle milk
}

\author{
K. Berisha ${ }^{1,2}$, H. Bytyçi ${ }^{2}, Z^{2}$. Mednyánszky ${ }^{1}$, E. Kiss ${ }^{3}$ and L. Simon-Sarkadi ${ }^{*}$
}

${ }^{1}$ Department of Food Chemistry and Nutrition, Faculty of Food Sciences, Szent István University, Somlói út 14-16, H-1118, Budapest, Hungary

${ }^{2}$ Department of Animal Science, Faculty of Agriculture and Veterinary, University of Prishtina Hasan Prishtina, Boulevard "Bill Clinton", 10 000, Prishtine, Kosovo

${ }^{3}$ Department of Genetics, Microbiology and Biotechnology, Faculty of Agricultural and Environmental Sciences, Szent Istvan University, Páter Károly u, 1, H-2100, Gödöllö, Hungary

\section{ORIGINAL RESEARCH PAPER}

Received: August 10, 2020 • Accepted: September 17, 2020

Published online: February 12, 2021

(C) 2020 The Author(s)

\begin{abstract}
To our knowledge, there is a lack of information on the nutrient composition of Busha cattle milk with special regard to its amino acid and biogenic amine contents. The Busha cattle breed is known to be highly resistant to various diseases and well-adapted to the extensive breeding conditions of the Balkan Peninsula. Busha cow milk contains an average of $13.47 \%$ dry matter, $4.34 \%$ fat, $3.72 \%$ protein, and $4.32 \%$ lactose. Significant differences were detected $(P<0.05)$ in the amino acid compositions of the milk of different Busha cattle strains of Kosovo. Glutamic acid, proline, leucine, aspartic acid, lysine, and valine represented $68 \%$ of the total amino acid content. Essential amino acids, branched-chain and sulphur-containing amino acids were found in substantial amounts in the milk samples. Among the biogenic amines, however, spermine $\left(0.16 \mathrm{mg} \mathrm{kg}^{-1}\right)$ and cadaverine $(0.09 \mathrm{mg}$ $\mathrm{kg}^{-1}$ ) were present in low concentrations. Due to these excellent qualities of the Busha cow milk, preservation of this cattle breed is of great importance. Developing sustainable and secured breeding and feeding programs for this endangered cattle breed of the Balkan Peninsula should also be a high priority.
\end{abstract}

\section{KEYWORDS}

amino acid, biogenic amines, milk, Busha cattle

\footnotetext{
*Corresponding author. Tel.: +1 3057 204, E-mail: simonne.sarkadi.livia@szie.hu
} 


\section{INTRODUCTION}

Busha cattle (Bos primigenius f. taurus) is a characteristic cattle breed of the Balkan Peninsula. Its breeding grounds in Kosovo are mainly in hilly and mountainous areas, where other breeds can hardly survive. Two strains of the Busha cattle breed are widespread in Kosovo: the Sharri Busha and the Dukagjini Busha. They produce an average of 1,322 $\mathrm{kg}$ milk in the lactation period (Krasniqi et al., 2013). The smaller Sharri Busha has a lower somatic cell count in its milk (72,840 SCC $\left.\mathrm{mL}^{-1}\right)$, which - according to milk quality standards in Kosovo - qualifies it to Class Extra (Bytyqi et al., 2013). The Dukagjin Busha is larger and produces more milk, while the Sharri Busha is better adapted to the harsh environment. Both strains are well-suited to extensive grazing and low-quality forage, have excellent maternal traits, and are characterised by easy calving. Also, they survive well under minimum livestock management, in mountainous and hilly areas; they are highly resistant to diseases, internal and external parasites (Bytyqi et al., 2007).

Beside meat production, the other main purpose of Busha cow husbandry is to produce milk, which is a basic source of nutrients of high biological value. Milk provides quality proteins, energy (fat and carbohydrates), minerals, and vitamins (Chalupa-Krebzdak et al., 2018). Summary report on proteins (WHO, 2007) by the World Health Organization, Food and Agriculture Organization, and the United Nations University (WHO/FAO/UNU) highlighted the important role of essential amino acids in human health and nutrition. Milk proteins (casein and whey proteins) are well known for their high-quality amino acid content (Gorissen et al., 2018). Branched-chain amino acids (BCAAs) present in milk proteins are necessary for many everyday activities, while cysteine is essential for healthy glutathione levels, antioxidant properties and also it helps the body combating various diseases (Ha and Zemel, 2003). The benefits of milk proteins in sports nutrition, infant formulae, and medical food supplements have also been recognised (Rafiq et al., 2016).

In addition to amino acids, other nitrogen-containing components also significantly determine milk quality. Polyamines, such as spermidine, spermine, putrescine, and cadaverine, are important in the regulation of nucleic acid function and protein synthesis and in the stabilisation of membranes (Kalac and Krausová, 2005). Biogenic amines (BA) mainly form as a result of microbial decarboxylation of amino acids in food. The formation of BA in food requires the availability of free amino acids, presence of decarboxylase-positive microorganisms, and favourable conditions for bacterial growth and decarboxylase activity (Simon Sarkadi, 2017). In high concentrations, biogenic amines - especially histamine and tyramine - are risk factors for food intoxication and may cause unpleasant allergic symptoms like cardiac palpitations, headache, nausea, diarrhea, and flushing. In extreme cases, the intoxication may have fatal outcome, whereas at moderate level, it may lead to food intolerance (Linares et al., 2012). Several studies have reported low biogenic amine content in milk. Mainly spermine (SPM), spermidine (SPD), cadaverine, and putrescine were present in low concentrations in milk. The amount of physiologically beneficial polyamines (SPM, SPD) also reveals important information about the health status of the cow (Kalac and Krausová, 2005; Gloria et al., 2011).

The purpose of this research was to study the nutrient composition of different Busha cattles' milks from Kosovo, focussing on amino acid and biogenic amine composition. The significance of the current research is given by the fact that it is the first analysis, which provides information on the milk composition of Busha cattle breed. 


\section{MATERIALS AND METHODS}

\subsection{Sampling}

Samples were collected in the Dukagjin area of Kosovo from April to November, more precisely in the villages Stellc in Peja region and Rrenc and Xerc in Prizren region, where this breed is more common compared to other regions. Twenty milk samples $(100 \mathrm{~mL})$ each were taken from two strains of Busha cattle: Sharri and Dukagjini. Standard sampling methods were applied to obtain representative sample for analysis (CODEX, 2003, STAN 234-1999). Livestock farmers filled in a questionnaire (Boynton and Greenhalgh, 2004) to provide data on the animals, whose milk was taken. The ages of the cows were between 2 and 10 years, and the lactation period between 0 and 6 months.

\subsection{Physicochemical measurements}

Solid contents (fat, protein, lactose) of the milk samples were measured by LactoScope infrared spectrometer (Delta Instruments-LactoScope Filter C3+/C4+ Dairy Analyzer, PerkinElmer, Waltham, USA). Conductivity and $\mathrm{pH}$ were determined by a digital conductivity and $\mathrm{pH}$ meter EXTECH EC600 model (EXTECH Inc., Pittsburgh, USA).

\subsection{Amino acid determination}

Amino acid composition was determined after hydrolysation of milk samples. $600-800 \mathrm{mg}$ of milk samples were hydrolysed with $10 \mathrm{~mL} 6 \mathrm{M} \mathrm{L}^{-1} \mathrm{HCl}$ under nitrogen atmosphere in a closed hydrolysing vessel (KUTESZ, Budapest, Hungary) at $110{ }^{\circ} \mathrm{C}$ for $24 \mathrm{~h}$ in a block thermostat (FALC Instruments, Treviglio, Italy). Neutralisation was performed by adding $10 \mathrm{~mL} 4 \mathrm{M} \mathrm{L}^{-1}$ $\mathrm{NaOH}$ to the hydrolysed sample in a $25 \mathrm{~mL}$ volumetric flask and then filled up with distilled water. After the neutralisation, samples underwent double filtration: first through normal paper filter and then through a $0.25 \mu \mathrm{m}$ membrane filter (Nalgene, Rochester, USA). The analysis was carried out by an Automatic Amino Acid Analyzer AAA400 (Ingos Ltd., Prague, Czech Republic) equipped with an Ionex Ostion LCP5020 cation-exchange column $(22 \times 0.37 \mathrm{~cm})$. Colorimetric detections were accomplished at 570 and $440 \mathrm{~nm}$ (for Pro) after post column derivatisation with ninhydrin reagent (Rabie et al., 2009).

\subsection{Biogenic amine determination}

For biogenic amine determination, $3 \mathrm{~g}$ of milk sample was extracted with $10 \mathrm{~mL} 10 \%$ trichloroacetic acid for $1 \mathrm{~h}$ at room temperature at 100 r.p.m. using a Laborshake (Gerhardt $\mathrm{GmbH}$, Königswinter, Germany). Samples were filtered through a $0.22 \mu \mathrm{m}$ membrane filter (Nalgene, Rochester, USA). Biogenic amines were analysed by an Automatic Amino Acid Analyzer AAA400 (Ingos Ltd., Prague, Czech Republic) equipped with an Ostion LG ANB ionexchange resin $(70 \times 3.7 \mathrm{~mm})$ column. Separation was carried out by stepwise gradient elution using $\mathrm{Na}^{+} / \mathrm{K}^{+}$buffers. Ninhydrin was used as post column derivatisation reagent, and detection was performed at $570 \mathrm{~nm}$ (Rabie et al., 2009).

\subsection{Statistical analysis}

The normality of the differences was accepted by Shapiro-Wilk and D'Agostino test, while homogeneity of variances was confirmed by Leven's test. Significant differences between the 
means for conductivity were calculated by a one-way analysis of variance (ANOVA) followed by Tukey's test at $P<0.05$. On the other hand, significant differences between the means for protein, lactose, fat, total solids, amino acids, and biogenic amines were calculated by a multivariate analysis of variance (MANOVA) using Tukey's test at $P<0.05$. The statistical analysis was performed by IBMSPSS25 software (Peck et al., 2016).

\section{RESULTS AND DISCUSSION}

\subsection{Dry matter content, $\mathrm{pH}$, and conductivity of milk samples}

Dry matter is an indicator of the amount of nutrients in food. Water is the major component of milk: usually it contains 81-89\% of water depending on the type of animal (Kanwal et al., 2004). The mean dry matter (protein, fat, and lactose) content of Busha cattle breeds varied between 13.09-13.86\% (Table 1). Protein content of milk was similar (3.7\%) for both cattle strains. Higher amounts of fat and lactose were found in Dukagjini cattle milk (4.50; 4.44\%) than Sharri cattle milk $(4.18 ; 4.2 \%)$. MANOVA test showed significant differences between the milk samples of Sharri and Dukagjini cattle with regard to the total solid, fat, and lactose contents $(P<0.05)$. Dukagjini Busha milk showed higher values in all cases. No significant differences were found $(P>0.05)$ for the $\mathrm{pH}$ and conductivity of the milk samples. Mean $\mathrm{pH}$ value $(\mathrm{pH} 6.6)$ and conductivity $\left(4.14 \mathrm{mS} \mathrm{cm}^{-1}\right.$ ) of the milk was within the range of fresh milk: $\mathrm{pH}$ 6.5-6.7 (Capriţa, 2014) and 4.0-5.86 mS cm$~^{-1}$ (Norberg et al., 2004), showing the freshness/quality balance of the Busha cattle milk.

\subsection{Amino acid composition of the milk samples}

Amino acid compositions of different cow's milks including Busha milk are given in Table 2. The main amino acids of Busha milk were glutamic acid (15.19-24.54\%), proline (7.45-14.04\%), leucine (9.37-13.00\%), aspartic acid (6.50-10.59\%), lysine (6.97-9.56\%), and valine (5.50$6.88 \%)$, while the minor ones were cysteine $(0-0.87 \%)$ and methionine $(0.75-2.31 \%)$. The main amino acids represent around $68 \%$ of the total amino acid content of the Busha cattle milk. Amino acid composition of Busha breed milk was similar to that of Swedish cow milk. Glutamic acid (24.54\%) and proline (14.04\%) were much higher in Busha milk compared to Holstein Friesian $(17.19 ; 8.49 \%)$ and Brown Swiss milk (15.19; 7.45\%), while aspartic acid, isoleucine, and alanine concentration was lower in Busha milk compared to these breeds.

Table 1. Dry matter (\%), $\mathrm{pH}$, and conductivity $\left(\mathrm{mS} \mathrm{cm}^{-1}\right)$ of Busha cattle strains milk

\begin{tabular}{lrr}
\hline Milk & Sharri Busha* & Dukagjini Busha* $^{*}$ \\
\hline Fat (\%) & $4.18 \pm 0.9^{\mathrm{a}}$ & $4.50 \pm 0.9^{\mathrm{b}}$ \\
Protein (\%) & $3.70 \pm 0.4^{\mathrm{a}}$ & $3.74 \pm 0.4^{\mathrm{a}}$ \\
Lactose (\%) & $4.20 \pm 0.5^{\mathrm{a}}$ & $4.44 \pm 0.5^{\mathrm{b}}$ \\
Total solid (\%) & $13.09 \pm 0.8^{\mathrm{a}}$ & $13.86 \pm 0.8^{\mathrm{b}}$ \\
$\mathrm{pH}$ & $6.60 \pm 0.0^{\mathrm{a}}$ & $6.59 \pm 0.0^{\mathrm{a}}$ \\
Conductivity $\left(\mathrm{mS} \mathrm{cm}^{-1}\right)$ & $4.18 \pm 0.7^{\mathrm{a}}$ & $4.10 \pm 0.5^{\mathrm{a}}$ \\
\hline
\end{tabular}

*Number of samples $n=20$; values are mean \pm standard deviation; means within a row with different lowercase superscripts differ $(P<0.05)$. 
Table 2. Amino acid composition of milk of different cattle breeds (\%)

\begin{tabular}{|c|c|c|c|c|}
\hline $\begin{array}{l}\text { Milk samples Amino } \\
\text { acids (\%) }\end{array}$ & $\begin{array}{l}\text { Busha* } \\
\text { Present } \\
\text { study }\end{array}$ & $\begin{array}{l}\text { Holstein } \\
\text { Friesian } \\
\text { Bobe et al., } \\
(2009)\end{array}$ & $\begin{array}{c}\text { Brown Swiss } \\
\text { Bobe et al., } \\
(2009)\end{array}$ & $\begin{array}{c}\text { Swedish } \\
\text { Lindmark-Mansson et al., } \\
(2003)\end{array}$ \\
\hline Asp & $6.50 \pm 0.07$ & 10.36 & 10.59 & 7.64 \\
\hline Thr & $3.85 \pm 0.40$ & 5.02 & 5.37 & 4.08 \\
\hline Ser & $5.24 \pm 0.10$ & 5.69 & 5.60 & 5.50 \\
\hline Glu & $24.54 \pm 0.10$ & 17.19 & 15.19 & 20.80 \\
\hline Pro & $14.04 \pm 0.23$ & 8.49 & 7.45 & 9.40 \\
\hline Gly & $1.67 \pm 0.06$ & 4.49 & 4.31 & 1.79 \\
\hline Ala & $2.55 \pm 0.09$ & 6.46 & 7.07 & 3.18 \\
\hline Val & $5.50 \pm 0.60$ & 6.76 & 6.88 & 6.51 \\
\hline Cys & $0.58 \pm 0.20$ & ND & ND & 0.87 \\
\hline Met & $1.96 \pm 0.10$ & 0.75 & 1.10 & 2.31 \\
\hline Ile & $3.37 \pm 0.30$ & 4.22 & 5.34 & 5.44 \\
\hline Leu & $9.73 \pm 0.30$ & 12.48 & 13.00 & 9.37 \\
\hline Tyr & $4.19 \pm 0.50$ & 1.33 & 1.32 & 4.43 \\
\hline Phe & $4.02 \pm 0.10$ & 3.09 & 3.15 & 4.66 \\
\hline Lys & $6.97 \pm 0.30$ & 8.69 & 9.56 & 7.95 \\
\hline His & $2.35 \pm 0.30$ & 2.04 & 1.76 & 2.81 \\
\hline Arg & $2.93 \pm 0.02$ & 1.97 & 2.13 & 3.27 \\
\hline
\end{tabular}

*Values are means \pm SD based on 40 observations (mean values of milk samples of Sharri and Dukagjini Busha cattle strains), ND: not detected.

Milk proteins provide a favourable balance of amino acids composed of essential and nonessential amino acids in varying concentrations. Essential amino acids in Busha breed milk represent around $40 \%$ of the total amino acids, making this breed's milk a great resource of proteins with high nutritional value. The concentration of Thr, Val, Ile, and Lys (3.85; 5.50; 3.37; 6.97\%) was lower in Busha cattle breed (Table 2) compared to Holstein Friesian (5.02; 6.76; 4.22; 8.69\%), Brown Swiss (5.37; 6.885.34; 9.56\%), and Swedish cattle breed (4.08; 6.51; 5.44; 7.69\%), while Met, Phe, and His (1.96; 4.02; and 2.35\%) was higher compared to Holstein Friesian (0.75; 3.09; and 2.04\%) and Brown Swiss (1.10; 3.15 and 1.76\%), and lower compared to Swedish (2.31; 4.66 and 2.81\%). Holstein Friesian and Brown Swiss cattle milk (12.48, 13.00\%, respectively) showed higher concentration of Leu, while its content was lower in Swedish cattle milk (9.37\%) compared to Busha (9.73\%).

Branched-chain amino acids (leucine, isoleucine, and valine) found in the milk proteins play roles in several functions of the human body, like maintaining tissue growth, repairing and preventing catabolic actions while exercising (Ha and Zemel, 2003; Gleeson, 2005), and have significant role in weight control through glucose homeostasis and lipid metabolism. Ideal balance of branched-chain amino acids were found in Busha cattle milk (Leu 9.73\%, Ile 3.37\%, Val 5.50\%), supporting its nutritional value and health benefits.

Sulphur-containing amino acids have several functions: they are essential for maintaining health through normal cellular functions and antioxidant action (Mukwevho et al., 2014). Sulphur-containing amino acids in Busha cattle milk are present in relatively high concentration 
(methionine 1.96\%; cysteine 0.58\%). According to FAO/WHO (1973), the ideal daily intake of methionine and cysteine is $14 \mathrm{mg} \mathrm{kg}^{-1}$ for humans. Our results show that the milk of Busha cattle satisfies the daily demand for sulphur-containing amino acids. Methionine (1.96\%) concentration was higher in Busha cattle milk compared to Holstein Friesian (0.75\%) and Brown Swiss (1.10\%). In Holstein Friesian and Brown Swiss cattle milk, cysteine was not detected (Table 2).

Only a few amino acids showed significant difference $(P<0.05)$ between the amino acid compositions of the two kinds of Busha milk (Fig. 1). Milk of Dukagini Busha contained higher amount of Glu, Cys, Tyr, and His compared with the milk of Sharri Busha.

Differences in the milk composition of the two Busha strains may be influenced by a number of factors, such as genetic variation of the breeds, housing and feeding conditions, animal husbandry strategies: stage of lactation, parity, season, management or production system, geographical location, age, etc.

\subsection{Biogenic amine content of milk samples}

Biogenic amine content of the milk of the two Busha strains showed no significant differences. With respect to biogenic amines, only spermine (SPM) and cadaverine (CAD) were present in low amounts in the milk samples (Table 3). Similar results were reported in cow milk for CAD

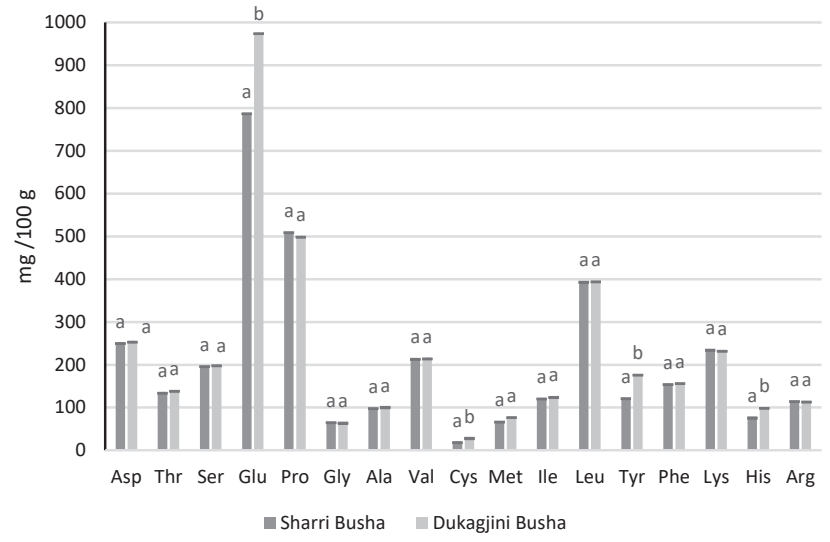

Fig. 1. Amino acid composition of Sharri Busha and Dukagjini Busha milk samples. Different letters represent significantly different values $(P<0.05)$. Number of observation $(n=20)$

Table 3. Biogenic amines in milk samples of Busha breed strains

\begin{tabular}{lcc}
\hline Biogenic amines & Sharri Busha mg kg & Dukagjini Busha mg kg \\
\hline CAD & $0.11 \pm 0.01$ & $0.07 \pm 0.02$ \\
SPM & $0.18 \pm 0.02$ & $0.15 \pm 0.02$ \\
Total BA & $0.29 \pm 0.03$ & $0.22 \pm 0.03$ \\
\hline
\end{tabular}

CAD: cadaverine; SPM: spermine; values are means \pm SD based on 20 observations. 
(0.11 $\left.\mathrm{mg} \mathrm{kg}^{-1}\right)$ by Min et al. (2004) and for SPM (0.20 mg kg-1) by Gloria et al. (2011). The milk of the Busha cow is also of excellent quality in terms of biogenic amine content.

\section{CONCLUSIONS}

This pioneering study is the first that provides valuable information on Busha cow's milk composition. The composition of Busha cow's milk showed high nutritional value. Significant differences were found only for few components of the milk despite some differences in the rearing conditions and the genetic variations of the breed strains. Further study is needed to develop sustainable and secure breeding and feeding programs to enhance the quality of the milk of these endangered cattle breeds of the Balkan Peninsula.

\section{ACKNOWLEDGEMENT}

Financial support for this study was provided by Tempus Public Foundation within the Stipendium Hungaricum Scholarship program and the Department of Food Chemistry and Nutrition of Doctoral School of Food Science of Szent István University. We are gratefully acknowledging the contribution of all farmers who provided information and milk samples from their farms.

\section{REFERENCES}

Bobe, G., Hippen, A.R., She, P., Lindberg, G.L., Young, J.W., and Beitz, D.C. (2009). Effects of glucagon infusions on protein and amino acid composition of milk from dairy cows. Journal of Dairy Science, 92(1): 130-138.

Boynton, P.M. and Greenhalgh, T. (2004). Selecting, designing, and developing your questionnaire. BMJ: British Medical Journal, 328(7451): 1312-1315.

Bytyqi, H., Odegard, J., Mehmeti, H., Vegara, M., and Klemetsdal, G. (2007). Environmental sensitivity of milk production in extensive environments: a comparison of Simmental, Brown Swiss, and Tyrol Grey using random regression models. Journal of Dairy Science, 90(8): 3883-3888.

Bytyqi, H., Vehapi, I., Rexhepi, S., Thaqi, M., Sallahi, D., and Mehmeti, I. (2013). Impact of bacterial and somatic cells content on quality fresh milk in small-scale dairy farms in Kosovo. Food and Nutrition Sciences, 4(10): 1014.

Capriţa, R. (2014). Evaluation of some physicochemical properties of milk caused by acidification. Scientific Papers Animal Science and Biotechnologies, 47(2): 137-141.

Chalupa-Krebzdak, S., Long, C.J., and Bohrer, B.M. (2018). Nutrient density and nutritional value of milk and plant-based milk alternatives. International Dairy Journal, 87: 84-92.

CODEX STAN. (2003). Recommended methods of analysis and sampling. STAN 234-1999, Available at: http://www.fao.org/fileadmin/user_upload/agns/pdf/CXS_234e.pdf.

FAO/WHO. (1973). Energy and protein requirements. Report of a Joint FAO/WHO Ad Hoc expert committee. Technical Report Series No. 552; FAO Nutrition Meetings Report Series 52. World Health Organization, Rome, p. 118. 
Gleeson, M. (2005). Interrelationship between physical activity and branched-chain amino acids. The Journal of Nutrition, 135(6): 1591-1595.

Gloria, M.B.A., Saraiva, P.R., Rigueira, J.C., and Brandao, S.C. (2011). Bioactive amines changes in raw and sterilised milk inoculated with Pseudomonas fluorescens stored at different temperatures. International Journal of Dairy Technology, 64(1): 45-51.

Gorissen, S.H., Crombag, J.J., Senden, J.M., Waterval, W.H., Bierau, J., Verdijk, L.B., and van Loon, L.J. (2018). Protein content and amino acid composition of commercially available plant-based protein isolates. Amino Acids, 50(12): 1685-1695.

Ha, E. and Zemel, M.B. (2003). Functional properties of whey, whey components, and essential amino acids: mechanisms underlying health benefits for active people. The Journal of Nutritional Biochemistry, 14(5): 251-258.

Kalac, P. and Krausová, P. (2005). A review of dietary polyamines: formation, implications for growth and health and occurrence in foods. Food Chemistry, 90(1-2): 219-230.

Kanwal, R., Ahmed, T., and Mirza, B. (2004). Comparative analysis of quality of milk collected from buffalo, cow, goat and sheep of Rawalpindi/Islamabad region in Pakistan. Asian Journal of Plant Sciences, 3(3): 300-305.

Krasniqi, F., Bytyqi, H., Kamberi, M., Hajrip, M., and Kastrati, R. (2013). Milk production of Busha cow breed kept in pasture. In: 1st International Conference on "Research and Education - Challenges Towards the Future"(ICRAE2013). Available at: http://konferenca.unishk.edu.al/icrae2013/icraecd2013/ doc/695.pdf (Accessed: 5 February 2020).

Linares, D.M., del Río, B., Ladero, V., Martínez, N., Fernández, M., Martín, M.C. and Álvarez, M.A. (2012). Factors influencing biogenic amines accumulation in dairy products. Frontiers in Microbiology, 3: 180.

Lindmark-Månsson, H., Fondén, R., and Pettersson, H.E. (2003). Composition of Swedish dairy milk. International Dairy Journal, 13(6): 409-425.

Min, J.S., Lee, S.O., Jang, A., Lee, M., and Kim, Y. (2004). Quantitative analysis of biogenic amines in raw and processed foods of animal origin on Korean domestic market. Asian-Australian Journal of Animal Sciences, 17(12): 1764-1768.

Mukwevho, E., Ferreira, Z., and Ayeleso, A. (2014). Potential role of sulfur-containing antioxidant systems in highly oxidative environments. Molecules: A Journal of Synthetic Chemistry and Natural Product Chemistry, 19(12): 19376-19389.

Norberg, E., Hogeveen, H., Korsgaard, I.R., Friggens, N.C., Sloth, K.H.M.N., and Lovendahl, P. (2004). Electrical conductivity of milk: ability to predict mastitis status. Journal of Dairy Science 87(4): 10991107.

Peck, R., Olsen, C., and Devore, J.L. (2016). Introduction to statistics and data analysis. Cengage Learning, USA. Available at: https://www.cengage.com/resource_uploads/downloads/1305115341_450336.pdf.

Rabie, M., Simon Sarkadi, L., Siliha, H., El Seedy, S., and El Badawy, A.A. (2009). Changes in free amino acids and biogenic amines of Egyptian salted-fermented fish (Feseekh) during ripening and storage. Food Chemistry, 115: 635-638.

Rafiq, S., Huma, N., Pasha, I., Sameen, A., Mukhtar, O., and Khan, M.I. (2016). Chemical composition, nitrogen fractions and amino acids profile of milk from different animal species. Asian-Australasian Journal of Animal Sciences, 29(7): 1022.

Simon-Sarkadi, L. (2017). Biogenic amines in fermented foods and health implications, Section 4, Chapter 27. In: Frias, J., Martinez-Villaluenga, C., and Penas, E. (Eds.), Fermented foods in health and disease prevention. Elsevier Academic Press, pp. 625-651. 
WHO. (2007). Protein and amino acid requirements in human nutrition: report of a joint FAO/WHO/ UNU expert consultation. Geneva, 2007. WHO Technical Report Series, 935, Available at: http://www. who.int/iris/handle/10665/43411 (Accessed: 11 June 2020).

Open Access. This is an open-access article distributed under the terms of the Creative Commons Attribution 4.0 International License (https://creativecommons.org/licenses/by/4.0/), which permits unrestricted use, distribution, and reproduction in any medium, provided the original author and source are credited, a link to the CC License is provided, and changes - if any - are indicated. (SID_1) 